\title{
PENGUKURAN KUALITAS LAYANAN DENGAN HIGHER EDUCATION PERFORMANCE (HEdPERF) DAN HIGHER EDUCATION SERVICE QUALITY (HiEdQUAL)
}

\author{
Ika Widya Ardhyani', Moses Laksono Singgih² \\ ${ }^{1}$ Teknik Industri, Fakultas Teknik \\ Universitas Maarif Hayim Latif, Sidoarjo, Indonesia \\ e-mail :ika.widya.ardhyani@gmail.com
}

${ }^{2}$ Departemen Teknik Industri, Fakultas Teknologi Industri

Institut Teknologi Sepuluh Nopember, Surabaya, Indonesia

e-mail : moseslsinggih@ie.its.ac.id

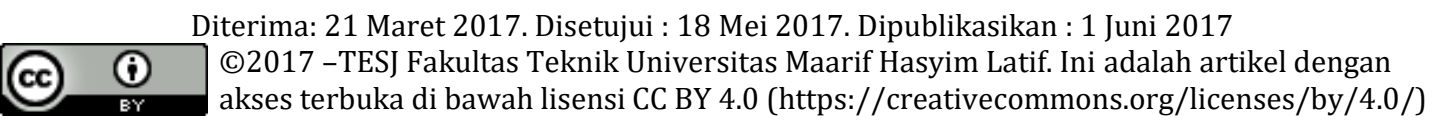

\section{ABSTRAK}

Kualitas layanan merupakan kunci sukses dalam pemasaran dan bisnis strategi. Peningkatan kualitas layanan terhadap perguruan tinggi merupakan hal yang perlu mendapatkan prioritas, karena kualitas layanan berhubungan erat dengan peningkatan keuntungan kompetitif. UMAHA merupakan universitas swasta di Sidoarjo. Sejak didirikan tahun 1998 hingga 2015 animo masyarakat terhadap UMAHA terus mengalami peningkatan hal ini ditunjukkan dengan semakin meningkatnya jumlah mahasiswa yang mendaftar. Namun disisi lain masih terjadi keluhan-keluhan terhadap pelayanan akademik. Berdasarkan hal tersebut, maka pengukuran kualitas layanan pendidikan yang akurat sangat penting dilakukan untuk mendapatkan gambaran yang lebih baik dan menjadi pedoman dalam melakukan suatu perbaikan. Itemitem dalam penelitian ini diadaptasi dari instrumen HEdPERF dan HiEdQUAL. Pengukuran kualitas layanan dalam penelitian ini akan dilakukan dengan responden dosen, staf administrasi dan mahasiswa sebagai pelanggan perguruan tinggi. Kuesioner digunakan untuk memperoleh data, berupa harapan dan persepsi. Teknik pengambilan sampel yang digunakan dalam penelitian ini adalah cluster sampling. Data yang diperoleh dianalisis dengan menggunakan uji validitas dan uji reliabilitas. Kualitas layanan akan di ukur dengan menggunakan model diskonfirmasi SERVQUAL, yang mendefinisikan kualitas dalam hal perbedaan yang muncul antara harapan pelanggan dan persepsi layanan yang sebenarnya. Hasil perhitungan skor SERVQUAL untuk ketiga responden, menunjukkan masing-masing item belum dapat memenuhi harapan pelanggan. Hal ini ditunjukkan dengan hasil perhitungan semua item yang bernilai negatif.

Kata Kunci: HEdPERF, HiEdQUAL, Kualitas Layanan, SERVQUAL

\section{PENDAHULUAN}

Dalam Tjiptono (2011) menyatakan kualitas jasa atau layanan memberikan kontribusi yang signifikan terhadap penciptaan positioning, differensiasi dan strategi bersaing setiap organisasi pemasaran, baik untuk penyedia jasa atau layanan maupun perusahaan manufaktur.

Faganel (2010) menyatakan, dalam rangka untuk mena-rik mahasiswa, melayani kebutuhan mahasiswa serta mempertahankan mahasiswa, perguruan tinggi harus secara aktif terlibat dalam proses memahami harapan dan persepsi mahasiswa mengenai kualitas layanan. Brochado (2009) menyatakan bahwa identifikasi dan implementasi alat ukur yang tepat akan mendapatkan pemaha- man yang lebih baik dalam menghadapi permasalahan kualitas layanan mahasiswa. Bahkan, penggunaan alat ukur yang tepat akan membantu institusi dalam menilai kualitas pelayanan yang diberikan, sehingga didapatkan hasil yang memiliki kemampuan untuk mendisain pelayanan yang lebih baik. Menurut Tjiptono (2004) tanpa pengukuran, suatu institusi atau perusahaan tidak akan dapat memahami dengan akurat apa yang terjadi pada sikap, persepsi dan perilaku kon-sumen sebagai respon terhadap aktivitas pemasaran yang dilakukan. Pengukuran kualitas layanan yang dirancang untuk mengukur harapan dan persepsi pelanggan serta gap diantara keduanya dalam dimensi utama kualitas layanan, merupakan upaya pemenuhan kebutuhan dan keinginan pelanggan serta ketepatan 
penyampaiannya untuk memenuhi keinginan pelanggan. Menurut Tjiptono (2011), keunggulan dari suatu layanan diharapkan dapat memuaskan pelanggan, meningkatkan penjualan produk dan jasa dari suatu perusahaan, serta dapat meningkatkan pendapatan perusahaan.

UMAHA merupakan universitas muslim swasta di bawah naungan Lembaga Pendidikan Tinggi Nahdlatul Ulama' (LPTNU) wilayah Sidoarjo. UMAHA merupakan penggabungan dari beberapa Sekolah Tinggi dan Akademi dilingkungan Yayasan Pendidikan dan Sosial Ma'arif (YPM) Sidoarjo dan baru disahkan menjadi Universitas pada 28 November 2014. UMAHA mengalami pertumbuhan yang sangat pesat. Oleh sebab itu, UMAHA terus mengembangkan sumberdayanya. Namun di sisi lain masih terjadi beberapa permasalahan yang dihadapi, di antaranya adalah keluhan-keluhan mahasiswa terhadap pelayanan akademik. Salim (2011) dalam penelitiannya, menyatakan bahwa kualitas layanan institusi yang masih rendah dapat menyebabkan kehilangan pelanggan. Berdasarkan hal tersebut, maka pengukuran kualitas layanan pendidikan yang akurat sangat penting dilakukan untuk mendapatkan gambaran yang lebih baik dan menjadi pedoman dalam melakukan suatu perbaikan.

Item-item dalam penelitian ini akan mengadopsi item-item dari instrumen HEdPERF dan HiEdQUAL dalam pengukuran kualitas layanan di UMAHA. Evaluasi kualitas layanan akan menggunakan model SERVQUAL mencakup perhitungan perbedaan di antara nilai yang diberikan para pelanggan untuk setiap pasangan pernyataan yang berkaitan dengan harapan dan persepsi pelanggan.

\section{METODE PENELITIAN}

Penelitian ini dilakukan atas beberapa tahap, yaitu tahap identifikasi masalah dan tahap pengukuran.

\section{Tahap Identifikasi}

Tahap ini terdiri dari beberapa langkah, yaitu: preliminary literatur study, studi literatur, studi lapangan identifikasi permasalahan, penentuan tujuan penelitian. Preliminary literatur study dilakukan dengan membaca berbagai referensi, baik berupa jurnal, buku, skripsi, tesis dan artikel publikasi yang berhubungan dengan penelitian. Studi literatur ini dilakukan dengan tujuan agar penelitian yang dilakukan lebih terarah karena memiliki dasar dan pedoman yang kuat dalam menyelesaikan masalah dan mencapai tujuan penelitian. Studi lapangan dilakukan dengan cara melakukan pengamatan pada objek amatan. Studi lapangan yang dilakukan berupa pengamatan kondisi layanan pendidikan di Fakultas Teknik Universitas Maarif Hasyim Latif (UMAHA) Sidoarjo. Setelah mendapatkan topik dan permasalahan yang akan diteliti, kemudian dilakukan pengidentifikasian masalah. Pada tahap ini dilakukan penetapan objek amatan yang digunakan untuk melakukan penelitian. setelah didapatkan objek amatan, maka identifikasi permasalahanpermaslahan yang akan diselesaikan. Pada tahap ini juga dilakukan penetapan area penelitian, yang meliputi batasan dan ruang lingkup permasalahan. Dengan adanya permasalahan-permasalahan yang dihadapi oleh objek amatan, kemudian ditentukan tujuan dari penelitian yang dilakukan.

\section{Tahap Pengukuran}

Pada tahap ini, akan dilakukan penentuan sampel penelitian, pengambilan data, dan pengolahan data.

Populasi dalam penelitian ini adalah dosen, staf administrasi dan mahasiswa di Fakultas Teknik UMAHA Sidoarjo. Data di kumpulkan dari dosen, staf administrasi dan mahasiswa yang telah menyelesaikan setidaknya satu tahun masa mengajar, bekerja dan pendidikan per November 2015. Teknik pengambilan sampel dalam penelitian ini adalah cluster sampling. Dalam penelitian ini pengambilan data diperoleh dari penyebaran kuesioner. Item-item pernyataan diperoleh dari penggabungan antara instrumen Higher Education Performance (HEdPERF) dan Higher Education Service Quality (HiEdQUAL). Penelitian ini menggunakan 7 dimensi dengan 38 item penelitian. Kualitas layanan dinilai dengan skala likert 5 poin, untuk tingkat kepentingan $1=$ sangat tidak setuju, 2 =tidak setuju, $3=$ kurang setuju, $4=$ setuju, 5=sangat setuju.

Tabel 1. Item-item penelitian

\begin{tabular}{|c|l|}
\hline NO. & \multicolumn{1}{|c|}{ Item-Item Penelitian } \\
\hline 1. & $\begin{array}{l}\text { ASPEK AKADEMIS } \\
\text { mahasiswa }\end{array}$ \\
\hline 2. & $\begin{array}{l}\text { Dosen mempunyai pengetahuan yang memadai dalam } \\
\text { menjawab pertanyaan mahasiswa, yang berhubungan } \\
\text { dengan materi kuliah }\end{array}$ \\
\hline 3. & Dosen menyediakan program dengan silabus yang lengkap \\
\hline 4. & Dosen mengajar sesuai dengan jadwal \\
\hline 5. & $\begin{array}{l}\text { Alokasi waktu mengajar dosen sesuai dengan alokasi } \\
\text { waktu yang ditentukan }\end{array}$ \\
\hline 6. & Dosen mudah untuk dihubungi \\
\hline 7. & Dosen menyampaikan materi dengan baik \\
\hline 8. & $\begin{array}{l}\text { Dosen memberikan materi sesuai dengan program dan } \\
\text { silabus }\end{array}$ \\
\hline 9. & $\begin{array}{l}\text { UMAHA menginformasikan jadwal kuliah, jadwal ujian, } \\
\text { hasil ujian, dll. }\end{array}$ \\
\hline 10. & Dosen menyelesaikan silabus tepat waktu \\
\hline 11. & UMAHA memiliki dosen yang memadai \\
\hline & \multicolumn{2}{|c|}{ LAYANAN ADMINISTRASI } \\
\hline 12. & $\begin{array}{l}\text { Staf administrasi menunjukkan rasa simpati dalam } \\
\text { memecahkan masalah mahasiswa }\end{array}$ \\
\hline 13. & Staf administrasi merespon permintaan bantuan dengan \\
\hline
\end{tabular}




\begin{tabular}{|c|l|}
\hline NO. & \multicolumn{1}{|c|}{ Item-Item Penelitian } \\
\hline 14. & $\begin{array}{l}\text { Staf administrasi menyediakan dan memberikan layanan } \\
\text { sesuai dengan yang dijanjikan }\end{array}$ \\
\hline 15. & Staf administrasi dapat berkomunikasi dengan baik \\
\hline 16. & $\begin{array}{l}\text { Staf administrasi memiliki pengetahuan yang baik tentang } \\
\text { sistem atau prosedur institusi }\end{array}$ \\
\hline 17. & $\begin{array}{l}\text { Staf administrasi bekerja sesuai dengan waktu dan lokasi } \\
\text { yang ditentukan }\end{array}$ \\
\hline 18. & $\begin{array}{l}\text { Administrasi menerima dan mencatat transaksi dengan } \\
\text { akurat }\end{array}$ \\
\hline
\end{tabular}

Tabel 1. Item-item penelitian(lanjutan)

\begin{tabular}{|c|c|}
\hline NO. & Item-Item Penelitian \\
\hline \multicolumn{2}{|r|}{ REPUTASI } \\
\hline 19. & $\begin{array}{l}\text { Mahasiswa diberikan kebebasan dalam memperoleh hak } \\
\text { dan kewajibannya }\end{array}$ \\
\hline 20. & UMAHA menjaga kerahasiaan informasi mahasiswa \\
\hline 21. & $\begin{array}{l}\text { UMAHA mempertimbangkan umpan balik dari mahasiswa } \\
\text { untuk memperbaiki kinerja layanan }\end{array}$ \\
\hline 22. & $\begin{array}{l}\text { UMAHA memiliki dan menerapkan standar pelayanan } \\
\text { dengan baik }\end{array}$ \\
\hline 23. & $\begin{array}{l}\text { UMAHA memiliki langkah-langkah keselamatan dan } \\
\text { keamanan }\end{array}$ \\
\hline \multicolumn{2}{|r|}{ ISU PROGRAM } \\
\hline 24. & UMAHA memiliki program pengembangan kampus \\
\hline 25. & $\begin{array}{l}\text { UMAHA mempunyai prodi yang dibutuhkan di dunia kerja } \\
\text { dan masyarakat }\end{array}$ \\
\hline \multicolumn{2}{|r|}{ FASILITAS AKADEMIK } \\
\hline 26. & Ukuran kelas sesuai untuk proses belajar mengajar \\
\hline 27. & Ruang kelas dilengkapi dengan alat bantu pengajaran \\
\hline 28. & UMAHA memiliki cukup ruang kelas \\
\hline 29. & $\begin{array}{l}\text { UMAHA memiliki auditorium dan ruang konferensi yang } \\
\text { memadai }\end{array}$ \\
\hline 30. & $\begin{array}{l}\text { Perpustakaan memiliki fasilitas akademik / pembelajaran } \\
\text { yang memadai }\end{array}$ \\
\hline 31. & $\begin{array}{l}\text { Laboratorium komputer memiliki peralatan dan fasilitas } \\
\text { internet yang memadai }\end{array}$ \\
\hline 32. & UMAHA menyediakan laboratorium teknik yang memadai \\
\hline \multicolumn{2}{|r|}{ INFRASTRUKTUR KAMPUS } \\
\hline 33. & $\begin{array}{l}\text { UMAHA memiliki fasilitas yang memadai (kantin, masjid, } \\
\text { area parkir, dll) }\end{array}$ \\
\hline 34. & Infrastruktur kampus terpelihara dengan baik \\
\hline 35. & UMAHA menyediakan layanan kesehatan yang memadai \\
\hline \multicolumn{2}{|r|}{ LAYANAN PENDUKUNG } \\
\hline 36. & UMAHA memberikan layanan konseling \\
\hline 37. & $\begin{array}{l}\text { UMAHA mengembangkan dan meningkatkan keberadaan } \\
\text { himpunan mahasiswa }\end{array}$ \\
\hline 38. & Fasilitas olahraga memadai \\
\hline
\end{tabular}

Pengolahan data dilakukan dengan cara uji validitas dan uji reliabilitas. Pengukuran kualitas layanan menggunakan model SERVQUAL mencakup perhitungan perbedaan untuk setiap pasang pertanyaan yang berkaitan dengan harapan dan persepsi.

\section{HASIL DAN PEMBAHASAN}

\section{Pengambilan Data}

Dalam penelitian ini metode yang digunakan untuk memperoleh informasi dari responden adalah berbentuk angket atau kuisioner. Kuesioner yang digunakan bersifat tertutup dengan skala likert. Draf kuesioner terdiri dari tiga bagian, bagian pertama adalah identitas responden. Bagian kedua dan ketiga, berisi itemitem penelitian yang disajikan dalam bentuk pernyataan untuk skala penilaian harapan dan kenyataan. Item-item pernyataan diperoleh dari penggabungan antara instrumen Higher Education Performance (HEdPERF) dan Higher Education Service Quality (HiEdQUAL).

Populasi dalam penelitian ini adalah dosen, staf administrasi dan mahasiswa di Fakultas Teknik UMAHA. Kuesioner dibagikan secara acak kepada dosen, staf administrasi, dan mahasiswa. Jumlah kuesioner yang dibagikan sebanyak 183 kuesioner. Didapatkan kuesioner yang sesuai, yaitu 18 kuesioner dosen, 12 kuesioner staf administrasi dan 127 kuesioner mahasiswa. Menghasilkan angka respon sebesar 86\% untuk dosen, $100 \%$ untuk staf administrasi dan $85 \%$ untuk mahasiswa.

2. Uji Validitas Kuesioner

Uji validitas digunakan untuk mengetahui kevalidan angket atau kuesioner dalam mengumpulkan data penelitian. Dalam penelitian ini pengujian validitas dilakukan dengan menggunakan korelasi Bivariate Perason (Produk Momen Pearson) dan Corrected ItemTotal Correlation, dengan taraf kepercayaan 95\% dan tingkat ketelitian $(\alpha)$ sebesar 5\%. Pengujian validitas kuesioner dilakukan pada masingmasing kuesioner yaitu bagian kedua dan ketiga. Dari hasil analisis diketahui bahwa semua nilai dari $r$ hitung $>r$ tabel yang artinya adalah semua item untuk penilaian harapan dan kenyataan dalam kuesioner bagian kedua dan ketiga dinyatakan valid.

3. Uji Reliabiltas Kuesioner

Uji reliabilitas digunakan untuk mengetahui konsistensi apakah alat ukur yang digunakan dapat diandalkan dan tetap konsisten jika pengukuran tersebut diulang. Dalam penelitian ini pengujian reliabilitas kuesioner dilakukan dengan metode Cronbach's Alpha. Item dikatakan reliabel jika nilai Cronbach's Alpha lebih besar dari $r$ tabel. Pengujian reliabilitas kuesioner dilakukan pada masing-masing bagian kuesioner yaitu bagian kedua dan ketiga. diketahui bahwa nilai Cronbach's Alpha itemitem pada penilaian harapan sebesar 0,933. Nilai ini kemudian dibandingkan dengan nilai $r$ tabel dengan $\mathrm{N}=157$, dicari pada distribusi nilai $\mathrm{r}$ tabel signifikan 5\% dan diperoleh nilai $r$ tabel sebesar 0,1567. Kesimpulannya adalah Cronbach's Alpha $=0,933>r$ tabel $=0,1567$ artinya reliabel. Korelasi berada pada kategori sangat kuat. Sedangkan nilai Cronbach's Alpha untuk item-item pada penilaian kenyataan sebesar 0,914. Nilai ini kemudian dibandingkan dengan nilai $r$ tabel dengan $\mathrm{N}=157$, dicari pada distribusi nilai $r$ tabel signifikan $5 \%$ dan diperoleh nilai $r$ tabel sebesar 
0,1567. Kesimpulannya adalah Cronbach's Alpha $=0,914>r_{\text {tabel }}=0,1567$ artinya reliabel. Korelasi berada pada kategori sangat kuat.

4. Perhitungan Skor SERVQUAL

Kualitas layanan diukur dengan menggunakan model SERVQUAL mencakup perhitungan perbedaan di antara nilai yang diberikan para pelanggan untuk setiap pasangan pernyataan yang berkaitan dengan harapan dan persepsi. Skor SERVQUAL untuk setiap pasang pernyataan, untuk masing-masing responden dihitung berdasarkan rumus berikut dalam Tjiptono (2011):

Skor SERVQUAL = Skor Persepsi - Skor Harapan
Faganel, A. (2010). "Quality Perception Gap Inside The Higher Education Institusion." International Journal of Academic Research 2(1).

Salim, A., M. L. Singgih, et al. (2011). "Pengukuran Kualitas Layanan Menggunakan SERVQUAL dan Confirmatory Factor Analysis (CFA) (Studi Kasus pada Jurusan Teknik Industri Universitas XYZ)." Prosiding Seminar Nasional Manajemen Teknologi XIII.

Tjiptono, F. and Gregorius, C. (2011). Service, Quality \& Satisfaction. Penerbit Andi, Yogyakarta.

Tjiptono, F., Y. Chandra, et al. (2004). Marketing Scales. Penerbit Andi Yogyakarta, Yogyakarta.

\section{PENUTUP}

Berdasarkan perhitungan skor SERVQUAL diketahui bahwa semua item untuk responden dosen, staf administrasi dan mahasiswa memiliki nilai negatif, yang berarti bahwa semua item belum memenuhi harapan pelanggan.

\section{DAFTAR PUSTAKA}

Brochado, A. (2009). "Comparing Alternative Instruments to Measure Service Quality in Higher Education." Quality Assurance in Education 17(2): 174-190. 


\section{Lampiran}

Tabel 2. Rekapitulasi perhitungan skor SERVQUAL untuk responden dosen

\begin{tabular}{|c|c|c|c|c|c|}
\hline Dimensi & Item & $\begin{array}{c}\text { Skor } \\
\text { Kenyataan } \\
\text { (Persepsi) }\end{array}$ & $\begin{array}{c}\text { Skor } \\
\text { Harapan }\end{array}$ & Skor SEI & VQUAL \\
\hline \multirow{11}{*}{$\begin{array}{l}\text { Aspek } \\
\text { akademis }\end{array}$} & AA1 & 4,2778 & 4,5556 & $-0,2778$ & \multirow{11}{*}{$-0,5101$} \\
\hline & AA2 & 4,0556 & 4,6667 & $-0,6111$ & \\
\hline & AA3 & 3,8333 & 4,5556 & $-0,7222$ & \\
\hline & AA4 & 4,1667 & 4,6111 & $-0,4444$ & \\
\hline & AA5 & 4,1111 & 4,6111 & $-0,5000$ & \\
\hline & AA6 & 4,1111 & 4,3889 & $-0,2778$ & \\
\hline & AA7 & 4,2778 & 4,6111 & $-0,3333$ & \\
\hline & AA8 & 4,1111 & 4,5000 & $-0,3889$ & \\
\hline & AA9 & 4,0556 & 4,5000 & $-0,4444$ & \\
\hline & AA10 & 3,4444 & 4,2778 & $-0,8334$ & \\
\hline & AA11 & 3,7222 & 4,5000 & $-0,7778$ & \\
\hline \multirow{7}{*}{$\begin{array}{l}\text { Layanan } \\
\text { administrasi }\end{array}$} & LA1 & 3,7778 & 4,5000 & $-0,7222$ & \multirow{7}{*}{$-0,5952$} \\
\hline & LA2 & 3,8889 & 4,3889 & $-0,5000$ & \\
\hline & LA3 & 3,7778 & 4,4444 & $-0,6667$ & \\
\hline & LA4 & 4,1667 & 4,4444 & $-0,2778$ & \\
\hline & LA5 & 3,7778 & 4,3889 & $-0,6111$ & \\
\hline & LA6 & 4,0000 & 4,6111 & $-0,6111$ & \\
\hline & LA7 & 3,6111 & 4,3889 & $-0,7778$ & \\
\hline \multirow{5}{*}{ Reputasi } & $\mathrm{R} 1$ & 3,8889 & 4,5000 & $-0,6111$ & \multirow{5}{*}{$-0,9000$} \\
\hline & $\mathrm{R} 2$ & 4,0556 & 4,4444 & $-0,3889$ & \\
\hline & R3 & 3,4444 & 4,5556 & $-1,1111$ & \\
\hline & $\mathrm{R} 4$ & 3,6111 & 4,3333 & $-0,7222$ & \\
\hline & R5 & 2,7222 & 4,3889 & $-1,6667$ & \\
\hline \multirow{2}{*}{ Isu program } & IP1 & 3,9444 & 4,4444 & $-0,5000$ & \multirow{2}{*}{$-0,4444$} \\
\hline & IP2 & 4,1111 & 4,5000 & $-0,3889$ & \\
\hline \multirow{7}{*}{$\begin{array}{l}\text { Fasilitas } \\
\text { akademik }\end{array}$} & FA1 & 3,8889 & 4,5556 & $-0,6667$ & \multirow{7}{*}{$-1,1032$} \\
\hline & FA2 & 4,000 & 4,5000 & $-0,5000$ & \\
\hline & FA3 & 3,6111 & 4,5000 & $-0,8889$ & \\
\hline & FA4 & 2,8889 & 4,4444 & $-1,5556$ & \\
\hline & FA5 & 3,0000 & 4,5000 & $-1,5000$ & \\
\hline & FA6 & 3,8333 & 4,6111 & $-0,7778$ & \\
\hline & FA7 & 2,7222 & 4,5556 & $-1,8333$ & \\
\hline \multirow{3}{*}{$\begin{array}{l}\text { Infrastruktur } \\
\text { kampus }\end{array}$} & IK1 & 4,0000 & 4,2222 & $-0,2222$ & \multirow{3}{*}{$-0,7963$} \\
\hline & IK2 & 3,5556 & 4,3889 & $-0,8333$ & \\
\hline & IK3 & 2,8889 & 4,2222 & $-1,3333$ & \\
\hline \multirow{3}{*}{$\begin{array}{l}\text { Layanan } \\
\text { pendukung }\end{array}$} & LP1 & 2,8333 & 4,1667 & $-1,3333$ & \multirow{3}{*}{$-0,9630$} \\
\hline & LP2 & 4,0556 & 4,4444 & $-0,3889$ & \\
\hline & LP3 & 3,0000 & 4,1667 & $-1,1667$ & \\
\hline
\end{tabular}


Tabel 3. Rekapitulasi perhitungan skor SERVQUAL untuk responden staf administrasi

\begin{tabular}{|c|c|c|c|c|c|}
\hline Dimensi & Item & $\begin{array}{c}\text { Skor } \\
\text { Kenyataan } \\
\text { (Persepsi) }\end{array}$ & $\begin{array}{c}\text { Skor } \\
\text { Harapan }\end{array}$ & Skor SE & VQUAL \\
\hline \multirow{11}{*}{$\begin{array}{l}\text { Aspek } \\
\text { akademis }\end{array}$} & AA1 & 3,9167 & 4,2500 & $-0,3333$ & \multirow{11}{*}{$-0,6515$} \\
\hline & AA2 & 3,7500 & 4,3333 & $-0,5833$ & \\
\hline & AA3 & 3,4167 & 4,3333 & $-0,9167$ & \\
\hline & AA4 & 3,5000 & 4,5000 & $-1,0000$ & \\
\hline & AA5 & 3,5833 & 4,3333 & $-0,7500$ & \\
\hline & AA6 & 3,5833 & 4,3333 & $-0,7500$ & \\
\hline & AA7 & 3,9167 & 4,3333 & $-0,4167$ & \\
\hline & AA8 & 3,8333 & 4,4167 & $-0,5833$ & \\
\hline & AA9 & 4,1667 & 4,5833 & $-0,4167$ & \\
\hline & AA10 & 3,4167 & 4,1667 & $-0,7500$ & \\
\hline & AA11 & 3,5833 & 4,2500 & $-0,6667$ & \\
\hline \multirow{7}{*}{$\begin{array}{l}\text { Layanan } \\
\text { administrasi }\end{array}$} & LA1 & 3,8333 & 4,3333 & $-0,5000$ & \multirow{7}{*}{$-0,6190$} \\
\hline & LA2 & 3,5833 & 4,5833 & $-1,0000$ & \\
\hline & LA3 & 3,8333 & 4,2500 & $-0,4167$ & \\
\hline & LA4 & 4,0833 & 4,3333 & $-0,2500$ & \\
\hline & LA5 & 3,5833 & 4,2500 & $-0,6667$ & \\
\hline & LA6 & 3,6667 & 4,5833 & $-0,9167$ & \\
\hline & LA7 & 3,9167 & 4,5000 & $-0,5833$ & \\
\hline \multirow{5}{*}{ Reputasi } & R1 & 3,6667 & 4,3333 & $-0,6667$ & \multirow{5}{*}{$-0,6500$} \\
\hline & R2 & 3,8333 & 4,3333 & $-0,5000$ & \\
\hline & R3 & 3,8333 & 4,1667 & $-0,3333$ & \\
\hline & R4 & 3,6667 & 4,1667 & $-0,5000$ & \\
\hline & R5 & 3,0000 & 4,2500 & $-1,2500$ & \\
\hline \multirow{2}{*}{ Isu program } & IP1 & 3,6667 & 4,2500 & $-0,5833$ & \multirow{2}{*}{$-0,7083$} \\
\hline & IP2 & 3,7500 & 4,5833 & $-0,8333$ & \\
\hline \multirow{7}{*}{$\begin{array}{l}\text { Fasilitas } \\
\text { akademik }\end{array}$} & FA1 & 3,7500 & 4,2500 & $-0,5000$ & \multirow{7}{*}{$-1,0833$} \\
\hline & FA2 & 3,6667 & 4,5000 & $-0,8333$ & \\
\hline & FA3 & 3,1667 & 4,2500 & $-1,0833$ & \\
\hline & FA4 & 3,3333 & 4,2500 & $-0,9167$ & \\
\hline & FA5 & 3,0833 & 4,5000 & $-1,4167$ & \\
\hline & FA6 & 3,6667 & 4,7500 & $-1,0833$ & \\
\hline & FA7 & 2,8333 & 4,5833 & $-1,7500$ & \\
\hline \multirow{3}{*}{$\begin{array}{l}\text { Infrastruktur } \\
\text { kampus }\end{array}$} & IK1 & 4,0000 & 4,5000 & $-0,5000$ & \multirow{3}{*}{$-0,8611$} \\
\hline & IK2 & 3,5000 & 4,1667 & $-0,6667$ & \\
\hline & IK3 & 3,0000 & 4,4167 & $-1,4167$ & \\
\hline \multirow{3}{*}{$\begin{array}{l}\text { Layanan } \\
\text { pendukung }\end{array}$} & LP1 & 2,7500 & 4,2500 & $-1,5000$ & \multirow{3}{*}{$-1,2500$} \\
\hline & LP2 & 3,5833 & 4,2500 & $-0,6667$ & \\
\hline & LP3 & 2,5833 & 4,1667 & $-1,5833$ & \\
\hline
\end{tabular}


Tabel 4. Rekapitulasi perhitungan skor SERVQUAL untuk responden mahasiswa

\begin{tabular}{|c|c|c|c|c|c|}
\hline Dimensi & Item & $\begin{array}{c}\text { Skor } \\
\text { Kenyataan } \\
\text { (Persepsi) }\end{array}$ & $\begin{array}{c}\text { Skor } \\
\text { Harapan }\end{array}$ & \multicolumn{2}{|c|}{ Skor SERVQUAL } \\
\hline \multirow{11}{*}{$\begin{array}{l}\text { Aspek } \\
\text { akademis }\end{array}$} & AA1 & 3,8031 & 4,5433 & $-0,7402$ & \multirow{11}{*}{$-0,9427$} \\
\hline & AA2 & 3,9921 & 4,6220 & $-0,6299$ & \\
\hline & AA3 & 3,7244 & 4,5669 & $-0,8425$ & \\
\hline & AA4 & 3,3307 & 4,6142 & $-1,2835$ & \\
\hline & AA5 & 3,4488 & 4,5669 & $-1,1181$ & \\
\hline & AA6 & 3,6063 & 4,6457 & $-1,0394$ & \\
\hline & AA7 & 3,8425 & 4,6850 & $-0,8425$ & \\
\hline & AA8 & 3,7087 & 4,6063 & $-0,8976$ & \\
\hline & AA9 & 3,7638 & 4,7165 & $-0,9528$ & \\
\hline & AA10 & 3,4724 & 4,5827 & $-0,1102$ & \\
\hline & AA11 & 3,7480 & 4,6614 & $-0,9134$ & \\
\hline \multirow{7}{*}{$\begin{array}{l}\text { Layanan } \\
\text { administrasi }\end{array}$} & LA1 & 3,2598 & 4,6063 & $-1,3465$ & \multirow{7}{*}{$-1,131$} \\
\hline & LA2 & 3,1890 & 4,5748 & $-1,3858$ & \\
\hline & LA3 & 3,4094 & 4,4961 & $-1,0866$ & \\
\hline & LA4 & 3,4646 & 4,5748 & $-1,1102$ & \\
\hline & LA5 & 3,4882 & 4,4646 & $-0,9764$ & \\
\hline & LA6 & 3,5039 & 4,6063 & $-1,1024$ & \\
\hline & LA7 & 3,7244 & 4,6378 & $-0,9134$ & \\
\hline \multirow{5}{*}{ Reputasi } & $\mathrm{R} 1$ & 3,7480 & 4,6299 & $-0,8819$ & \multirow{5}{*}{$-1,0693$} \\
\hline & $\mathrm{R} 2$ & 3,8425 & 4,5669 & $-0,7244$ & \\
\hline & R3 & 3,6614 & 4,5433 & $-0,8819$ & \\
\hline & $\mathrm{R} 4$ & 3,5197 & 4,5354 & $-1,0157$ & \\
\hline & R5 & 2,6457 & 4,4882 & $-1,8425$ & \\
\hline \multirow{2}{*}{ Isu program } & IP1 & 3,7008 & 4,6299 & $-0,9291$ & \multirow{2}{*}{$-0,9055$} \\
\hline & IP2 & 3,8425 & 4,7244 & $-0,8819$ & \\
\hline \multirow{7}{*}{$\begin{array}{l}\text { Fasilitas } \\
\text { akademik }\end{array}$} & FA1 & 3,5906 & 4,5984 & $-1,0079$ & \multirow{7}{*}{$-1,5624$} \\
\hline & FA2 & 3,4252 & 4,6929 & $-1,2677$ & \\
\hline & FA3 & 3,1496 & 4,6929 & $-1,5433$ & \\
\hline & FA4 & 2,9921 & 4,5433 & $-1,5512$ & \\
\hline & FA5 & 3,0236 & 4,6693 & $-1,6457$ & \\
\hline & FA6 & 3,1339 & 4,7402 & $-1,6063$ & \\
\hline & FA7 & 2,4488 & 4,7638 & $-2,3150$ & \\
\hline \multirow{3}{*}{$\begin{array}{l}\text { Infrastruktur } \\
\text { kampus }\end{array}$} & IK1 & 3,7795 & 4,7244 & $-0,9449$ & \multirow{3}{*}{$-1,3622$} \\
\hline & IK2 & 3,3307 & 4,5591 & $-1,2283$ & \\
\hline & IK3 & 2,6220 & 4,5354 & $-1,9134$ & \\
\hline \multirow{3}{*}{$\begin{array}{l}\text { Layanan } \\
\text { pendukung }\end{array}$} & LP1 & 2,5512 & 4,4016 & $-1,8504$ & \multirow{3}{*}{$-1,5643$} \\
\hline & LP2 & 3,7717 & 4,6063 & $-0,8346$ & \\
\hline & LP3 & 2,4488 & 4,4567 & $-2,0079$ & \\
\hline
\end{tabular}


IW Ardhyani, dkk / Teknika, Vol. 1, No.1, Juni 2017, 25-32

Halaman ini sengaja dikosongkan 